OPEN ACCESS

Edited by:

Hanna Lotter,

Bernhard Nocht Institute for Tropical

Medicine (BNITM), Germany

Reviewed by:

Andreas Meinhardt

University of Giessen, Germany

Brian Becknell,

The Ohio State University,

United States

*Correspondence:

David A. Hunstad

dhunstad@wustl.edu

Specialty section:

This article was submitted to Cytokines and Soluble Mediators in

Immunity,

a section of the journal

Frontiers in Immunology

Received: 31 January 2020

Accepted: 18 June 2020

Published: 28 July 2020

Citation:

Hreha TN, Collins CA, Daugherty AL,

Griffith JM, Hruska KA and

Hunstad DA (2020)

Androgen-Influenced Polarization of Activin A-Producing Macrophages

Accompanies Post-pyelonephritic

Renal Scarring.

Front. Immunol. 11:1641.

doi: 10.3389/fimmu.2020.01641

\section{Androgen-Influenced Polarization of Activin A-Producing Macrophages Accompanies Post-pyelonephritic Renal Scarring}

\author{
Teri N. Hreha ${ }^{1}$, Christina A. Collins ${ }^{1}$, Allyssa L. Daugherty ${ }^{1}$, Jessie M. Griffith ${ }^{1}$, \\ Keith A. Hruska ${ }^{1,2}$ and David A. Hunstad ${ }^{1,3 *}$
}

${ }^{1}$ Department of Pediatrics, Washington University School of Medicine, St. Louis, MO, United States, ${ }^{2}$ Department of Cell Biology and Physiology, Washington University School of Medicine, St. Louis, MO, United States, ${ }^{3}$ Department of Molecular Microbiology, Washington University School of Medicine, St. Louis, MO, United States

Ascending bacterial pyelonephritis, a form of urinary tract infection (UTI) that can result in hospitalization, sepsis, and other complications, occurs in 250,000 US patients annually; uropathogenic Escherichia coli (UPEC) cause a large majority of these infections. Although UTIs are primarily a disease of women, acute pyelonephritis in males is associated with increased mortality and morbidity, including renal scarring, and end-stage renal disease. Preclinical models of UTI have only recently allowed investigation of sex and sex-hormone effects on pathogenesis. We previously demonstrated that renal scarring after experimental UPEC pyelonephritis is augmented by androgen exposure; testosterone exposure increases both the severity of pyelonephritis and the degree of renal scarring in both male and female mice. Activin $A$ is an important driver of scarring in non-infectious renal injury, as well as a mediator of macrophage polarization. In this work, we investigated how androgen exposure influences immune cell recruitment to the UPEC-infected kidney and how cell-specific activin A production affects post-pyelonephritic scar formation. Compared with vehicle-treated females, androgenized mice exhibited reduced bacterial clearance from the kidney, despite robust myeloid cell recruitment that continued to increase as infection progressed. Infected kidneys from androgenized mice harbored more alternatively activated (M2) macrophages than vehicle-treated mice, reflecting an earlier shift from a pro-inflammatory (M1) phenotype. Androgen exposure also led to a sharp increase in activin A-producing myeloid cells in the infected kidney, as well as decreased levels of follistatin (which normally antagonizes activin action). As a result, infection in androgenized mice featured prolonged polarization of macrophages toward a pro-fibrotic M2a phenotype, accompanied by an increase in M2a-associated cytokines. These data indicate that androgen enhancement of UTI severity and resulting scar formation is related to augmented local activin A production and corresponding promotion of $\mathrm{M} 2 \mathrm{a}$ macrophage polarization.

Keywords: urinary tract infection, activin A, follistatin, macrophage polarization, Escherichia coli 


\section{INTRODUCTION}

Urinary tract infections (UTIs) are extremely common, affecting millions of people worldwide. Uropathogenic strains of Escherichia coli (UPEC) cause over $80 \%$ of UTIs, including both bladder infections (cystitis) and ascending infection of the kidneys (pyelonephritis). UTIs predominantly affect females, though infant and elderly males exhibit higher rates of UTI compared to similarly aged females (1-6). Males also exhibit higher morbidity and mortality than females in the setting of complicated UTI $(4,7)$. Upper-tract UTI in childhood carries risk for renal scarring, which in turn correlates with risk of chronic kidney disease, and end-stage renal disease later in life (8-14). Our prior studies in mice demonstrated enhanced UTI severity and scar formation in males compared with females, phenotypes shown to be dependent on androgen exposure $(15,16)$.

Macrophage recruitment, polarization, and function are important for the proper resolution of many bacterial infections. In a typical response, circulating monocytes are recruited to the site of infection upon signaling by damage-associated and pathogen-associated molecular patterns (DAMPs and PAMPs), and proinflammatory cytokines such as IL-6, IFN $\gamma$, and TNF $\alpha$; these arriving monocytes initially differentiate, or polarize, toward proinflammatory (M1) macrophages (17-25). These M1 cells further secrete proinflammatory cytokines and chemokines, exert phagocytic activity, and induce neutrophil apoptosis (2530). Reduction of local DAMP and PAMP quantities, along with an increase in neutrophil debris, and accumulation of $\mathrm{T}_{\mathrm{H}} 2$ cytokines, including cytokines such as CXCL1, G-CSF, and IL10 (27, 31-33), subsequently encourages these M1 macrophages to polarize toward alternatively activated M2 macrophages (3438). M2a macrophages are activated by IL- 4 and IL-13, and are considered pro-fibrotic (39-42). These cells secrete TGF $\beta 1$ and are involved in cell growth, repair, and matrix deposition. Immune complexes and IL- $1 \beta$ stimulate M2b polarization, which is involved in regulation of the immune and inflammatory responses $(43,44)$. M2c macrophages are stimulated by IL10 , are involved in phagocytosis and matrix remodeling, and typically signal resolution of the inflammatory response to an injury (45-49).

Activin A, a TGF $\beta$ superfamily member that is a homodimer of inhibin $\beta_{A}$, has been shown to be upregulated in several different systemic infection or injury models (50-56). In models of non-infectious renal injury, activin A signaling promotes renal scarring and fibrosis (55-59); in other systems, activin A has been shown to exert varying effects on macrophage polarization. For example, it encourages an M1 phenotype on unstimulated monocytes and macrophages in vitro (60-63) but pushes these cells toward a M2 polarization state when they are primed with LPS (64-68).

Testosterone signaling increases susceptibility to, and severity of, experimental pyelonephritis and renal scars in both male and female mice (69), while anti-androgen treatments are protective against UTI in mice and in women with polycystic ovary syndrome $(16,70,71)$. Sex differences are also evident in the immune response to infection, and vary somewhat by model. Males tend to have more circulating M1 macrophages during infection (72), and dihydrotestosterone (DHT) can induce a prolonged M1 macrophage polarization state in vitro (73). Females typically exhibit more intense inflammatory responses to multiple microbial stimuli (including vaccines), and have more efficient phagocytic macrophages and increased levels of Tolllike receptors (TLRs) and pro-inflammatory cytokines $(74,75)$. In contrast, women taking oral contraceptives demonstrated a decrease in several pro-inflammatory cytokines (IFN $\gamma, \mathrm{TNF} \alpha$ ) after LPS stimulation (75), and testosterone stimulation has been shown to decrease the production of TLR4 in mice (76).

In mouse models of non-infectious renal injury, aberrant wound healing in males is characterized by increased leukocyte infiltrate and enhanced proteolysis of ECM, while castration promotes favorable wound healing $(77,78)$. Renal fibrosis in these models is also strongly associated with the presence of M2 macrophages (79-83); in fact, adoptive transfer of M2 macrophages after unilateral ureteral obstruction (UUO) promoted the accumulation of $\alpha \mathrm{SMA}+$ cells (indicative of fibrotic scarring), a phenotype that involved signaling by members of the TGF $\beta$ superfamily (84).

Here, we used C57BL/6 females treated with testosterone cypionate (TC) in order to investigate how activin A influences macrophage polarization during ascending pyelonephritis in the androgenized host. Although several studies have investigated how activin A affects macrophage polarization in vitro in the presence of LPS, data are sharply lacking on how these interactions transpire during in vivo infection. We determined that during ascending UPEC pyelonephritis, androgen exposure results in increased local activin $\mathrm{A}$ and promotes recruitment of activin A-producing leukocytes, particularly activin $\mathrm{A}+$ monocytes and macrophages. Further, androgenized mice exhibited decreased local IFN $\gamma$ and $\mathrm{TNF} \alpha$ along with increased CXCL1 and G-CSF, associated with decreased local M1:M2 macrophage ratios throughout infection. In particular, androgen exposure caused a persistent increase in pro-fibrotic M2a macrophages during later stages of infection. This androgendependent skewing toward $\mathrm{M} 2 \mathrm{a}$ macrophages promotes an environment of reduced bacterial clearance and enhanced renal scarring.

\section{MATERIALS AND METHODS}

\section{Bacterial Strains}

UTI89, a clinical cystitis isolate of uropathogenic Escherichia coli (UPEC) (85), was grown statically overnight in Luria-Bertani broth (LB; Becton Dickinson, Sparks, MD) at $37^{\circ} \mathrm{C}$. Overnight cultures were centrifuged for $10 \mathrm{~min}$ at $7,500 \times g$ at $4^{\circ} \mathrm{C}$ before resuspension in sterile phosphate-buffered saline (PBS) to a final density of $\sim 4 \times 10^{8}$ colony-forming units (CFU) $/ \mathrm{mL}$.

\section{Animals}

All animal protocols received prior approval from the Washington University Institutional Animal Care and Use Committee. Experiments were conducted in female C57BL/6 mice (\#000664; Jackson Laboratories, Bar Harbor, ME) or, for immunofluorescence analysis, in female bigenic Gli1-tdTomato ${ }^{+}$ mice, which harbor a tamoxifen-inducible Cre for tdTomato 
production from the Glil promoter [kind gift of B. Humphreys; (86)]. For androgenization, mice of either strain were given weekly intramuscular injections of $150 \mathrm{mg} / \mathrm{kg}$ testosterone cypionate (TC, Depo-Testosterone; Pfizer, New York, NY) beginning at $5 \mathrm{wk}$ of age, and continuing until sacrifice. UTI was initiated by inoculation of the bladder with $1-2 \times 10^{7} \mathrm{CFU}$ of UPEC via catheter at $7 \mathrm{wk}$ of age, as described previously $(87,88)$.

\section{Determination of Bacterial Loads}

At the indicated time points, mice were anesthetized with inhaled isoflurane (Patterson Veterinary, Greeley, CO) and terminally perfused with $4^{\circ} \mathrm{C}$ PBS through the left ventricle. Bladders and kidneys were aseptically removed and homogenized in $4^{\circ} \mathrm{C}$ PBS. The resulting tissue homogenates were serially diluted and plated on LB agar.

\section{Tissue Preparation and Histology}

Gli1-tdTomato ${ }^{+}$Mice were euthanized as described above, and aseptically removed kidneys were fixed in 4\% paraformaldehyde in PBS for $1 \mathrm{~h}$ at $4^{\circ} \mathrm{C}$, incubated overnight in 30\% sucrose in PBS at $4^{\circ} \mathrm{C}$, then embedded in OCT (Fisher Scientific, Hampton, NH). Embedded kidneys were cryosectioned into $5-8-\mu \mathrm{m}$ sections and mounted onto Superfrost Plus slides (Fisher Scientific). For immunofluorescence staining, sections were washed with PBS, blocked with $10 \%$ fetal bovine serum (FBS) in PBS, then stained with fluorescently conjugated primary antibodies against CD206Alexa Fluor 488 (1:200; Biolegend \#141709) and CD80-APC (1:200; Biolegend \#104713). Sections were then washed with PBS, stained with 1:5,000 4',6-diamidino-2-phenylindole (DAPI) and mounted with ProLong Gold (both from Life Technologies, Carlsbad, CA). Images were captured digitally with a Zeiss LSM 880 Airyscan confocal microscope (Oberkochen, Germany).

\section{Flow Cytometry}

Kidneys were harvested as described above, and were manually homogenized into cold RPMI (Gibco) before treatment with $\mathrm{RBC}$ lysis buffer $\left(155 \mathrm{mM} \mathrm{NH} 4 \mathrm{Cl}, 10 \mathrm{mM} \mathrm{KHCO}_{3}\right.$ ) at room temperature to ensure complete lysis of any remaining RBCs. After washing, cells were subjected to a Percoll gradient (Percoll PLUS; GE Healthcare, Uppsala, Sweden) in FACS buffer [10\% FBS, $1 \% \mathrm{w} / \mathrm{v}$ sodium azide, $2 \mathrm{mM}$ ethylenediaminetetraacetic acid (EDTA) in PBS] $+25 \mathrm{mM}$ sucrose for leukocyte enrichment, then resuspended in $4^{\circ} \mathrm{C}$ PBS and stained with Live/Dead Fixable Yellow (ThermoFisher Scientific). Cells were washed again, resuspended in $4^{\circ} \mathrm{C}$ FACS buffer and blocked with $\mathrm{Fc}$ Block (BD Biosciences, San Jose, CA) on ice, followed by staining with fluorescently conjugated antibodies against the following extracellular antigens: CD45-BV510 (1:200; BD Biosciences \#563891), NK1.1-AlexaFluor 700 (1:50; Biolegend \#108730, San Diego, CA), CD11c-AlexaFluor 700 (1:200; Biolegend \#117320), Ly6G-AlexaFluor 700 (1:200; Biolegend \#127621), CD19AlexaFluor 700 (1:200; Biolegend \#115527), CD3e-AlexaFluor 700 (1:100; BD Biosciences \#557984), CD150-APC (1:100; Biolegend \#115910), CD206-PE-Cy7 (1:100; Biolegend \#141719), CD86-PE-Cy5 (1:100; Biolegend \#105016), CD115-PE (1:100;
Biolegend \#135506), CD80-FITC (1:50; Biolegend \#104706). After staining, cells were washed, fixed in $4 \%$ paraformaldehyde in PBS, permeabilized on ice with Perm/Wash buffer $(10 \%$ FBS, $1 \%$ w/v sodium azide, $1.3 \mathrm{mM}$ saponin in $\mathrm{PBS}, \mathrm{pH} 7.4$ 7.6), and then stained with the intracellular antibody Inhibin $\beta_{\mathrm{A}}$-MaxLight405 (1:20; US Biological \#211496, Salem, MA). All macrophages described are $\mathrm{CD} 11 \mathrm{~b}+$ and Ly6C+. M1 macrophages are defined as CD80+, F4/80+, MHC-II lo. M2a macrophages are defined as CD206+ F4/80+ and MHC-II lo/-; $\mathrm{M} 2 \mathrm{~b}$ as CD86+, F4/80+/-, MHC-II lo/-; and M2c as CD150+, F4/80+/-, MHC-II hi (data not shown). For flow cytometry of whole-kidney activin A production, the kidneys were processed as described above, but cell suspensions were not subjected to the Percoll gradient. After blocking, cells were stained with labeled antibodies against the following extracellular antigens: E-cadherin (CD324)-PE-Cy7 (1:200, Biolegend \#147309), and CD45 (30-F11)-BV510 (1:200, BD Biosciences \#563891) and the intracellular antibody Inhibin $\beta_{\mathrm{A}}$-MaxLight405 (1:20; US Biological \#211496) as described above. Stained cells were washed, resuspended in FACS buffer and subjected to flow cytometry on a LSR II Fortessa instrument (BD Biosciences). Results were analyzed using FlowJo software (BD Biosciences). A representative gating scheme is provided in Figure $\mathbf{S 1}$.

\section{Immunoblotting}

Harvested kidneys were flash frozen in liquid nitrogen and stored at $-80^{\circ} \mathrm{C}$ until use. Kidneys were homogenized in RIPA buffer $(50 \mathrm{mM}$ Tris- $\mathrm{HCl}, 150 \mathrm{mM} \mathrm{NaCl}, 1 \% \mathrm{v} / \mathrm{v}$ Nonidet P40, $0.1 \% \mathrm{w} / \mathrm{v}$ SDS, $0.5 \% \mathrm{w} / \mathrm{v}$ sodium deoxycholate, $\mathrm{pH} 7.4$ ) containing PhosSTOP phosphatase inhibitor (Roche; Basel, Switzerland) and complete Mini protease inhibitor (Roche). The lysates were cleared by centrifugation $(2 \times 5 \mathrm{~min}$ at max speed in a tabletop centrifuge), followed by total protein quantification by BCA assay (Invitrogen, Carlsbad, CA). Eighty $\mu \mathrm{g}$ of protein was run on SDS-PAGE gels and transferred to PVDF membranes. Membranes were blocked with 5\% w/v nonfat milk (Carnation, Vaud, Switzerland) in PBS containing $0.05 \%$ $\mathrm{v} / \mathrm{v}$ Tween-20 (PBST), and probed with primary antibodies against follistatin (1:500; Invitrogen \# PA5-79284) and CoxIV (1:20,000; Cell Signaling Technologies \#4844, Danvers, MA) in blocking buffer overnight at $4^{\circ} \mathrm{C}$. Membranes were washed and probed 1:2,000 with the appropriate horseradish peroxidaseconjugated secondary antibody (GE Healthcare \#NAP34) in blocking buffer for $1 \mathrm{~h}$ at room temperature. Membranes were washed again and developed with the Clarity Western ECL Kit (Bio-Rad, Hercules, CA).

\section{Cytokine Quantification}

Protein was extracted from flash-frozen kidneys as described above, and diluted in PBS to $900 \mu \mathrm{g} / \mathrm{mL}$. The diluted protein was analyzed with a customized Bio-Plex Pro Mouse Cytokine Group I kit (Bio-Rad) according to the manufacturer's instructions. The plate was read with a Bio-Plex 200 system and analyzed using BioPlex Manager 6.1 software. 


\section{qPCR}

mRNA was extracted from flash-frozen kidneys using RNA Stat60 (amsbio, Cambridge, MA) according to package instructions. One $\mu \mathrm{g}$ mRNA was converted to cDNA using the iScript cDNA Synthesis Kit (Bio-Rad) according to package instructions. qPCR was performed with the SsoAdvanced Universal SYBR Green Supermix (Bio-Rad), containing $\sim 20 \mathrm{ng}$ of cDNA and $350 \mathrm{nM}$ primers. Thermal cycling was performed on a 7500 Fast RT-PCR system (Applied Biosystems, Foster City, CA) with the following protocol: $95^{\circ} \mathrm{C}, 3 \mathrm{~min} ; 40 \times\left(95^{\circ} \mathrm{C}, 10 \mathrm{~s} ; 60^{\circ} \mathrm{C}, 30 \mathrm{~s}\right)$. A list of primer sequences is provided in Table $\mathbf{S} \mathbf{S}$.

\section{Statistical Analysis}

Statistical analysis for CFU and Bio-Plex data was performed using the non-parametric Mann-Whitney U-test. All other statistics were performed with an unpaired $t$-test. $P<0.05$ were considered significant.

\section{RESULTS}

\section{Androgen Exposure Amplifies Renal Activin Expression During Pyelonephritis}

In agreement with our previous work $(16,69)$, TC-treated (androgenized) mice maintained consistently high UPEC titers in both bladders and kidneys, significantly higher than those in vehicle-treated mice beginning 14 days post infection (dpi; Figure 1). As infection progressed, kidneys of TC-treated mice had increased global transcription of Inhba (encoding activin A) beginning $14 \mathrm{dpi}$ and continuing through $28 \mathrm{dpi}$ (Figure 2A). This increased transcription led to modest but statistically significant increases in activin A production $28 \mathrm{dpi}$ by both epithelial (CD45- E-cadherin+; Figure 2B) and non-epithelial cells (CD45- E-cadherin-; Figure 2C), as determined by flow cytometry. This increase in activin A is consistent with similar increases seen in other renal injury models $(55,56)$. Meanwhile, the leukocyte $(\mathrm{CD} 45+)$ population in TC-treated mice showed a significant elevation of activin A production 14 dpi (Figure 2D). This activin burst was of much greater amplitude than that seen in the other cell populations, leading us to investigate further how activin production by leukocyte populations could associate with the reduced UPEC clearance and enhanced scar formation seen in the androgenized host.

\section{Follistatin Production Is Suppressed in Androgen-Exposed Mice With UTI}

Follistatin binds strongly to activin $\mathrm{A}$ in the circulation and tissues, preventing its binding to its cellular receptor and thereby rendering it inactive (89-91). We hypothesized that renal tubular epithelial cell death associated with UPEC infection would reduce local production of follistatin (16). Indeed, while wholekidney transcription of follistatin during UPEC infection was not altered in TC-treated mice (Figure 3A), follistatin production in whole-kidney homogenates was significantly reduced in TCtreated mice 10 and $14 \mathrm{dpi}$, as measured by quantitative immunoblot (Figures 3B,C). There was mild (but not statistically significant) reduction in follistatin production in androgenized mice across the other sampled time points (Figure 3C). Taken together, increased activin A production, coupled with decreased follistatin production, would provide an environment in the androgenized mouse kidney with increased activin A activity during UPEC infection.

\section{Androgenized Mice Harbor Increased Activin A-Producing Myeloid Cells in the Infected Kidney}

Activin A has been shown to affect macrophage polarization in vitro, encouraging M1 polarization in unstimulated macrophages while promoting M2 polarization in LPS-stimulated models (5664). We examined leukocyte $(\mathrm{CD} 45+)$ populations within the kidneys of TC-treated mice at various time points in order to interrogate the role of androgens in activin A-driven macrophage

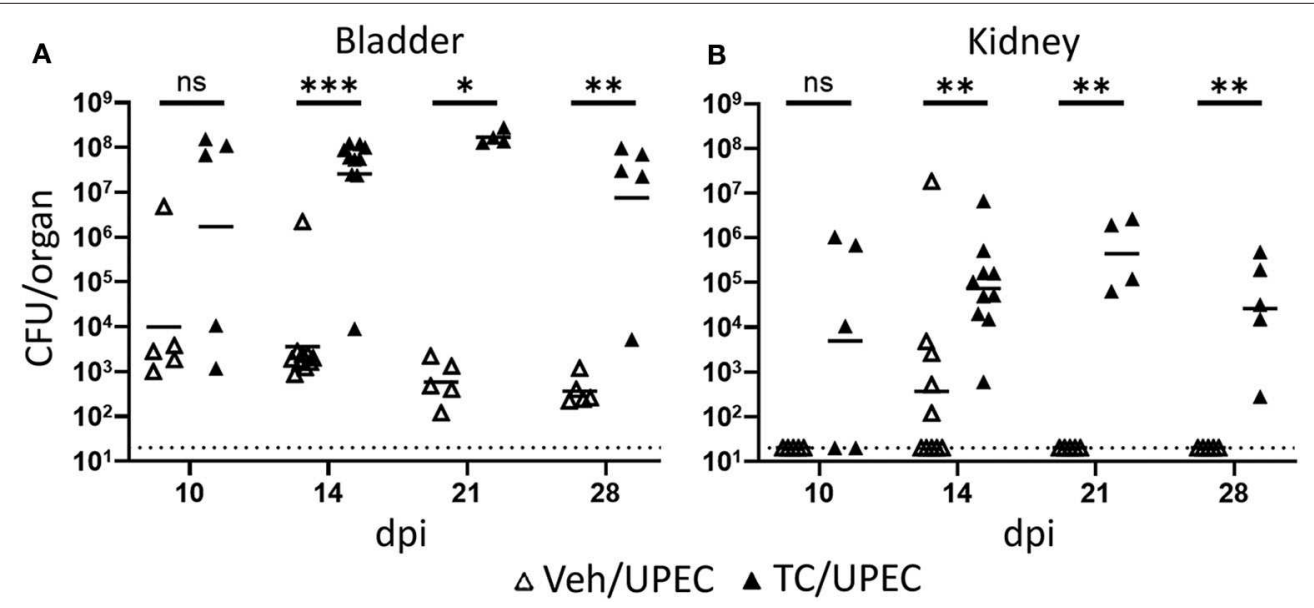

FIGURE 1 | Androgenized mice exhibit severe UTI. Organ titers (CFU) were quantified in serially diluted bladder (A) or kidney (B) homogenates at the indicated time points post UPEC infection of vehicle-treated mice (open triangles) or TC-treated mice (filled triangles). Dotted line indicates the limit of detection; dpi, days post-infection. $n=4-10$ mice per group. ${ }^{\star} P<0.05$, ${ }^{\star \star} P<0.01,{ }^{* \star \star} P<0.001$. 

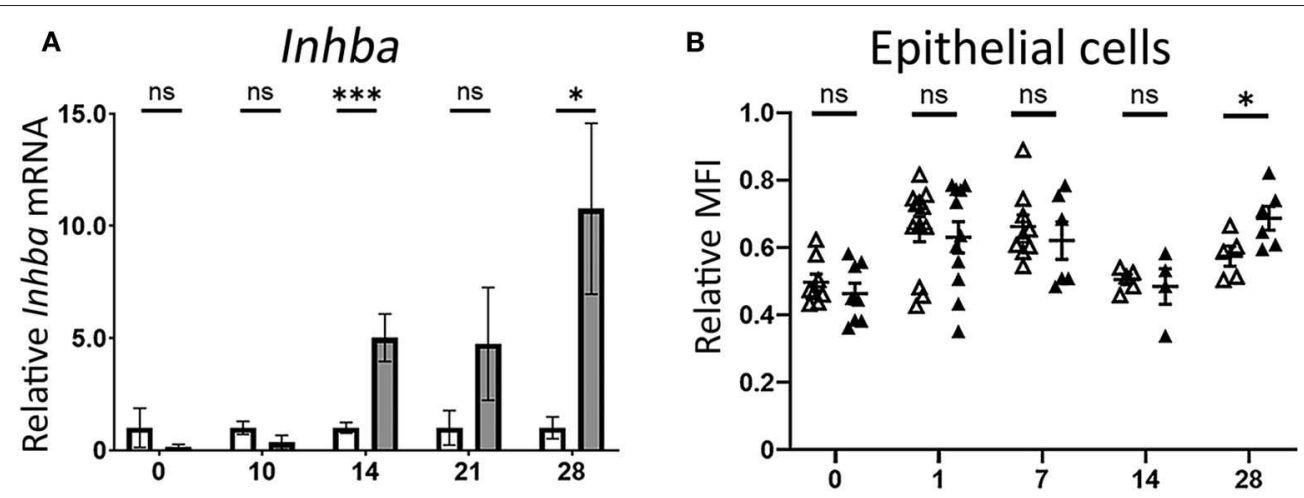

c Non-epithelial cells
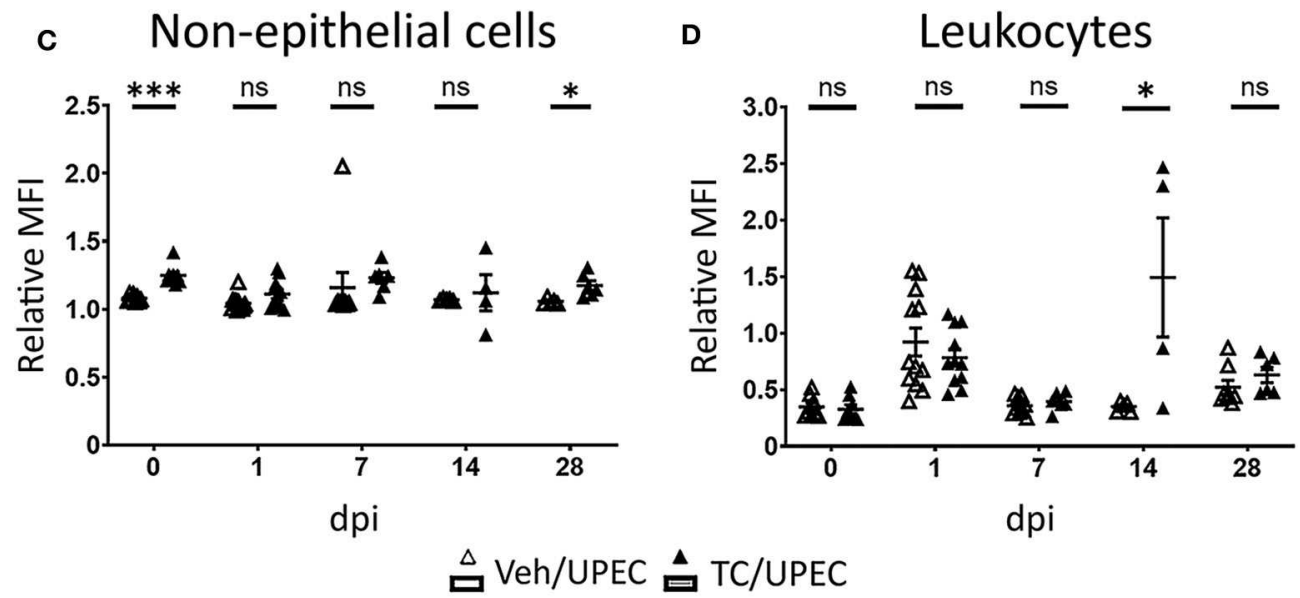

FIGURE 2 | Activin A expression and production is increased in the kidneys of androgenized mice. (A) Relative whole-kidney mRNA expression of Inhba was determined in vehicle-treated mice (open bars) and TC-treated mice (filled bars) by qPCR at various time points post UPEC infection. $n=4-8$ mice per group. The relative mean fluorescence intensity (MFI) of activin A in (B) epithelial cells (CD45- E-cadherin+), (C) non-epithelial cells (CD45- E-cadherin-), or (D) leukocytes (CD45+ E-cadherin-) compared to the MFI in the total live cell population was determined by flow cytometry at the indicated time points in vehicle-treated mice (open triangles) or TC-treated mice (filled triangles). $n=4-10$ mice per group. ${ }^{\star} P<0.05,{ }^{\star \star \star} P<0.001$.

polarization during pyelonephritis. After $14 \mathrm{dpi}$, TC-treated mice consistently exhibited increased recruitment of CD45+ cells to the kidneys compared to vehicle-treated mice (Figure 4A). While most of these CD45+ cells were neutrophils (Ly6G+; data not shown), TC-treated mice displayed a sustained increase in both monocyte (CD19- CD3e- Ly6G- CD11c- NK1.1CD115+) and macrophage (CD19- CD3e- Ly6G- CD11cNK1.1- CD115-) populations in the kidneys starting $14 \mathrm{dpi}$ (Figures 4C,E). There were also more activin A+ leukocytes, monocytes, and macrophages in the kidneys of androgenized mice, indicating that both the monocyte and macrophage populations were contributing to activin A signaling in the infected kidney (Figures 4B,D,F).

\section{Androgen Exposure Favors Polarization of Renal Macrophages Toward the Pro-fibrotic M2a Phenotype}

To investigate how the increased levels of activin A affected macrophage polarization during UPEC infection and resolution, we quantified kidney macrophages in the M1 or M2 polarization states at various time points. Compared with vehicle-treated mice, androgenized mice harbored an increased population of M1 macrophages (CD80+; Figure 5A) in the kidneys 14 and 21 $\mathrm{dpi}$, and an even greater increase in M2 macrophages from 14 to 28 dpi (CD80-; Figure 5B). This led to an overall decrease in the M1:M2 ratio, beginning $10 \mathrm{dpi}$ and sustained throughout the course of infection (Figure 5C). A prolonged reduction in the M1:M2 ratio is reflective of aberrant wound healing and is associated with fibrotic scarring (25).

Within the population of activated macrophages, the M1 phenotype predominated in both vehicle and TC-treated mice throughout the course of infection; however, androgenized mice showed a significant reduction at multiple time points in the fraction of polarized macrophages that were M1 (Figure 6A). Correspondingly, androgenized mice exhibited a significant increase in M2a (CD206+, CD150-) macrophages, beginning $14 \mathrm{dpi}$ and persisting through the remainder of the course (Figure 6B). Both M1 and M2a macrophages were visualized near populations of Gli1+ activated myofibroblasts, which are the major producers of extracellular matrix proteins in fibrotic injury (Figure S2) $(86,92)$. Vehicle- and TC-treated mice showed 

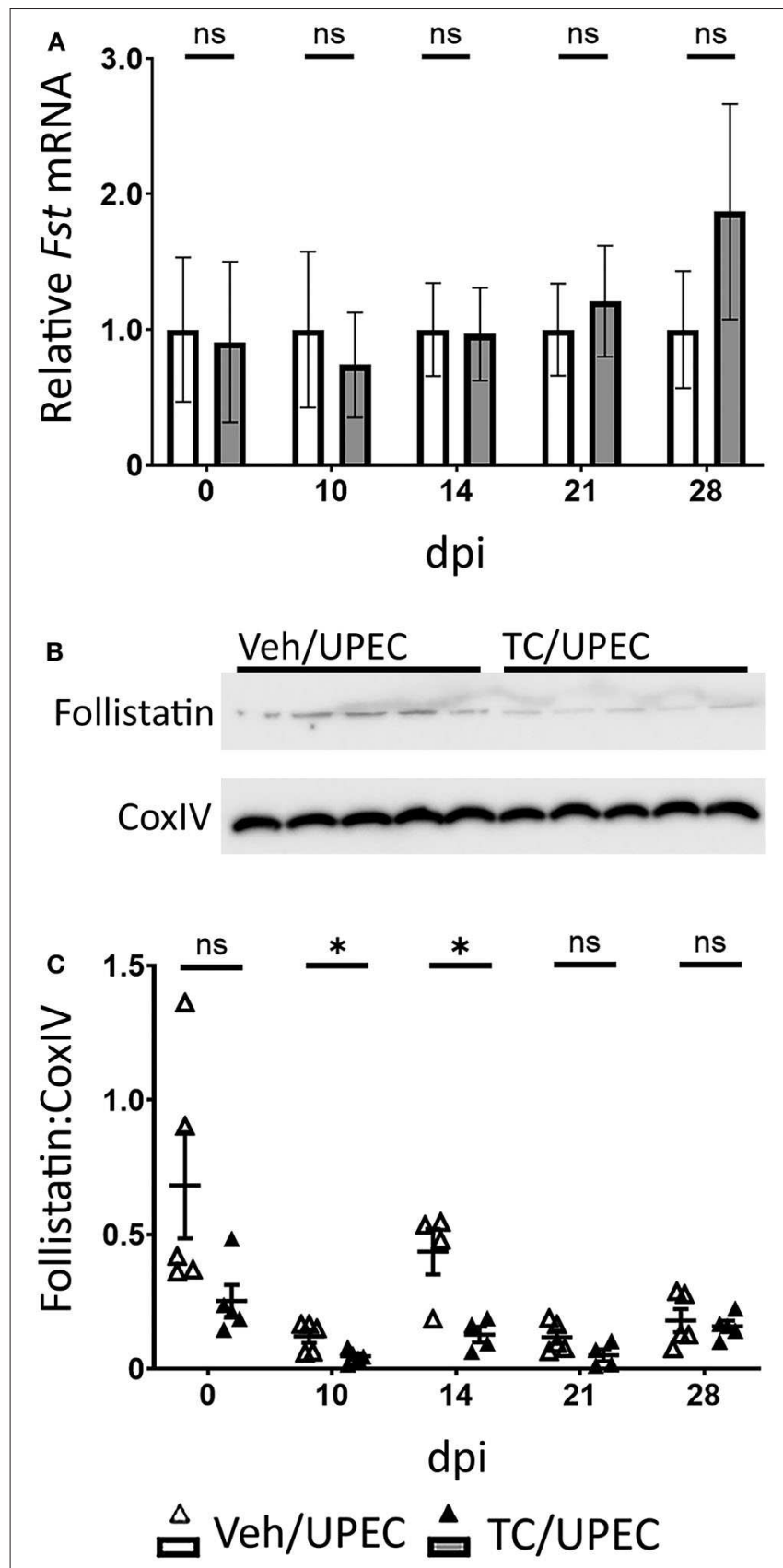

FIGURE 3 | Follistatin production is reduced during pyelonephritis in androgenized mice. (A) Relative whole-kidney Fst mRNA was measured by qPCR at the indicated time points in vehicle-treated mice (open bars) and TC-treated mice (filled bars). $n=4-8$ mice per group. Whole-kidney protein production of follistatin was determined by quantitative western blot [representative blot shown in (B); quantitation in (C)] at the indicated time points in vehicle-treated mice (open triangles) and TC-treated mice (filled triangles). $n=4-5$ mice per group. ${ }^{\star} P<0.05$.

equivalent increases in $\mathrm{M} 2 \mathrm{~b}(\mathrm{CD} 86+)$ macrophages at later time points following infection (Figure 6C). Vehicle- and TCtreated mice also harbored similar proportions of $\mathrm{M} 2 \mathrm{c}(\mathrm{CD} 150+)$ macrophages in the kidneys until $28 \mathrm{dpi}$, when androgenized mice had significantly more (Figure 6D). These results indicate that androgens promote activin A production by myeloid cells responding to UPEC pyelonephritis, with a corresponding increase in $\mathrm{M} 2 \mathrm{a}$ polarization of renal macrophages.

\section{Androgens Promote M2a-Associated Cytokine Expression During Pyelonephritis}

M2a macrophages have been associated with tissue fibrosis after non-infectious injury (39, 40, 93, 94). These cells secrete a number of cytokines and chemokines involved in immunomodulation and repair, including TGF $\beta 1$, a chief signaling factor in renal fibrosis $(84,95,96)$. Further, adoptive transfer of M2a macrophages led to reduced healing and increased fibrosis of endometriotic lesions (97). We investigated cytokine content in the kidneys of vehicle and TC-treated mice throughout infection. Notably, among M1-associated cytokines, IFN $\gamma$ was significantly reduced in androgenized mouse kidneys 10 dpi (Figure 7A), while TNF $\alpha$ was unaltered by androgen exposure (Figure 7B). Meanwhile, M2-activating cytokines CXCL1 and G-CSF were significantly increased in TCtreated mice at multiple time points (compared with vehicletreated; Figures 7C,D), indicating that the cytokine profile of the infected, androgenized kidney may help to drive recruited macrophages toward the M2 polarization state. In line with the flow cytometry data (Figure 6B), TC treatment did not alter the level of M2b stimulant IL-1 $\beta$ in the kidneys (Figure 7E) and acted to depress production of the M2c stimulant IL-10 (Figure 7F). This lack of increase in IL-1 $\beta$ and IL-10 may discourage progression of M2a macrophages toward the M2b and M2c phenotypes that would characterize an optimal healing process.

\section{DISCUSSION}

Our published studies showed that testosterone exposure favors the development of severe pyelonephritis in both $\mathrm{C} 3 \mathrm{H}$ and C57BL/6 mice $(16,69)$, with exacerbation of post-pyelonephritic scarring. The present work demonstrates that androgens encourage a reduction in pro-inflammatory M1 macrophages in the UPEC-infected kidney, conversely favoring the sustained presence of pro-fibrotic M2a macrophages, prolonging UTI and offering a cellular basis for the altered resolution and enhanced scarring we demonstrated previously.

Activin A, a member of the TGF $\beta$ superfamily, is involved in both healing and renal fibrosis in several models (55-59) and is a major driver of macrophage polarization (56-64). TC-treated mice demonstrated an increase in Inhba transcription and activin A production throughout their kidneys, with a corresponding decrease in follistatin. The cumulative result of these effects is more active activin $\mathrm{A}$ in the kidneys of androgen-exposed mice. Interestingly, the CD45+ leukocyte population in TC-treated mice showed the most pronounced increase in activin A (14 dpi); correspondingly, infiltration of multiple myeloid lineages was enhanced in androgenized mice, and the number of activin A-producing cells in these groups also steadily increased.

Activin A signaling has been shown to encourage recruited monocytes to differentiate into either pro-inflammatory M1 

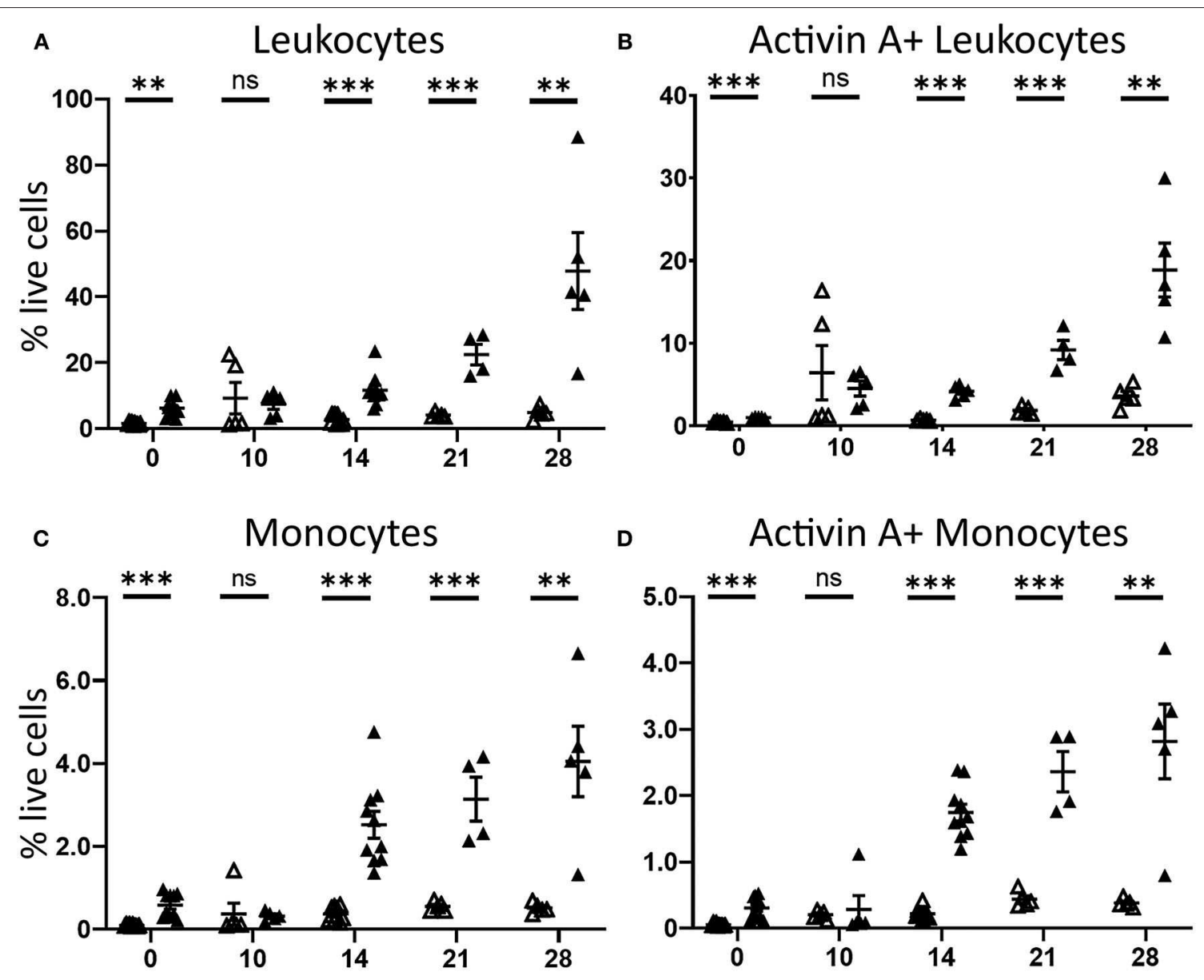

D Activin A+ Monocytes
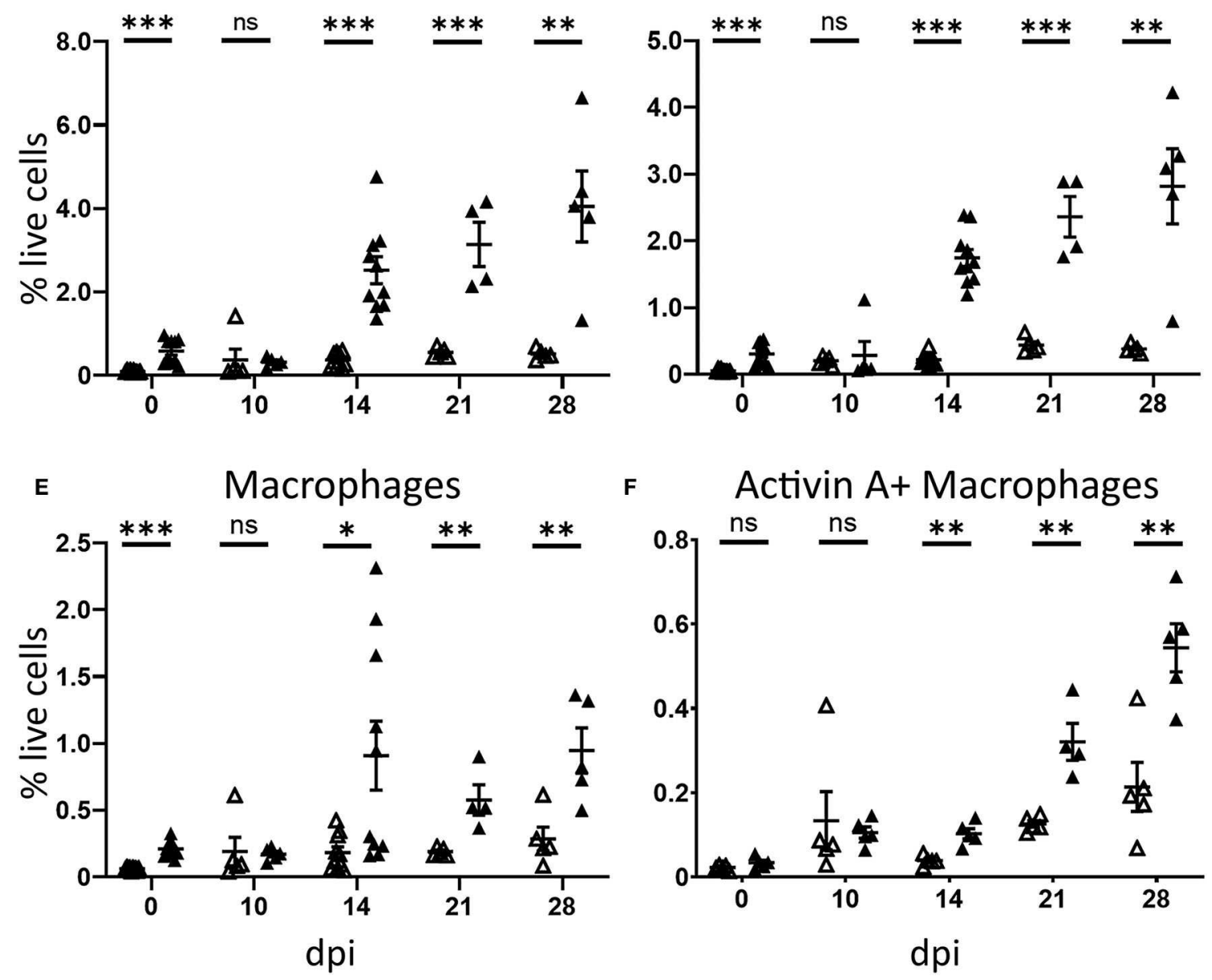

F Activin A+ Macrophages

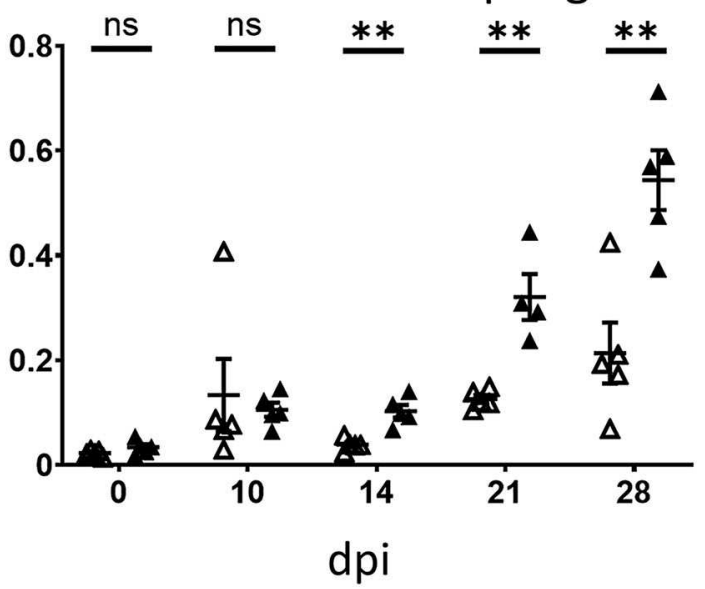

$\triangle$ Veh/UPEC $\triangle \mathrm{TC} / \mathrm{UPEC}$

FIGURE 4 | Androgenized mice have larger populations of activin A-producing leukocytes, including monocytes and macrophages, in the kidneys during UPEC infection. The population of (A) total leukocytes (CD45+), (B) activin A+ leukocytes, (C) monocytes (CD45+ CD115+ CD19- CD3e- Ly6G- CD11C- NK1.1-), (D) activin $A+$ monocytes, (E) macrophages (CD45+ CD115- CD19- CD3e- Ly6G- CD11C- NK1.1-), and (F) activin A+ macrophages as a percentage of the total live cell population was determined by flow cytometry in vehicle-treated mice (open triangles) and TC-treated mice (filled triangles) at the indicated time points. $n=$ 4-10 mice per group. ${ }^{\star} P<0.05,{ }^{\star \star} P<0.01,{ }^{\star \star \star} P<0.001$. 

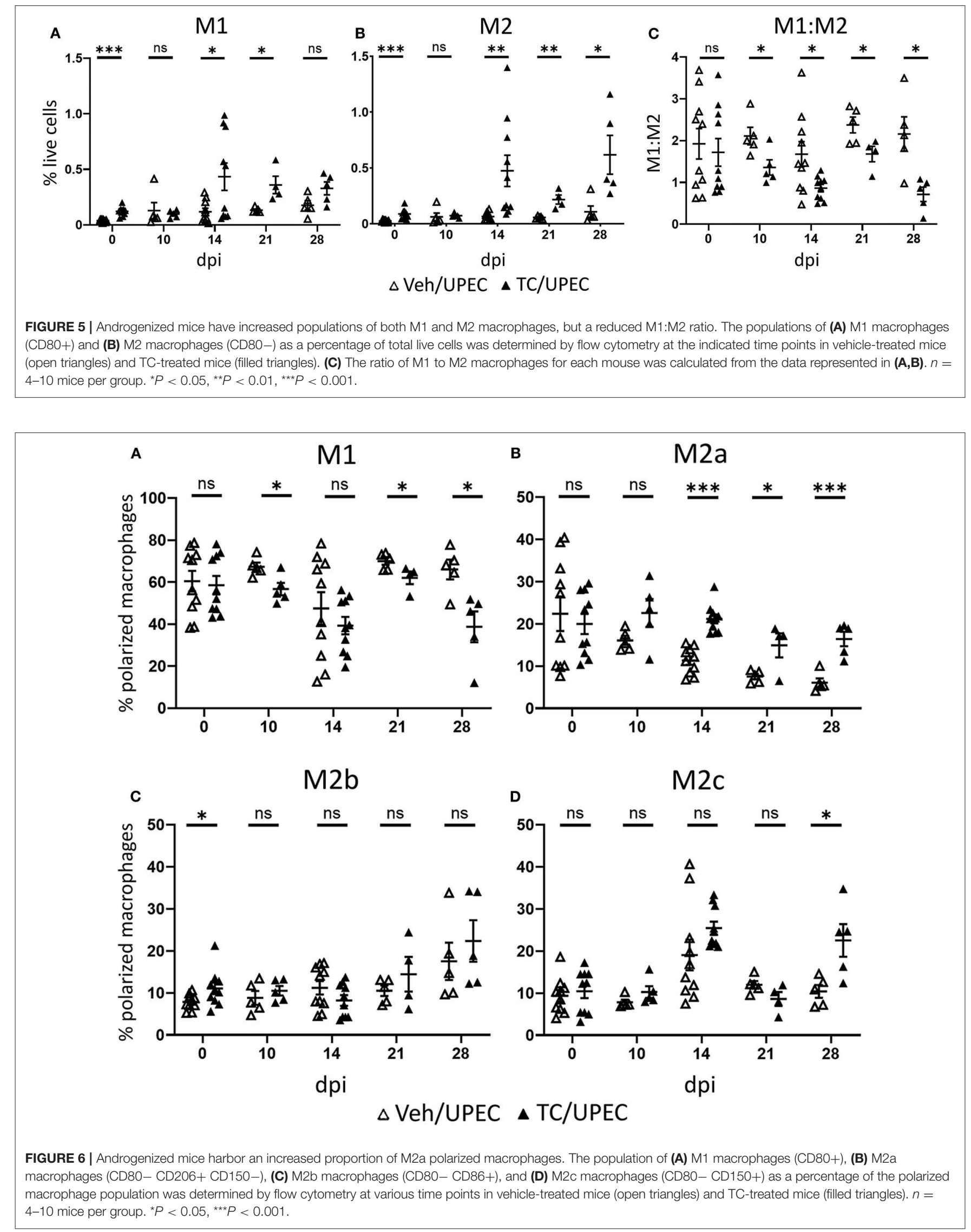


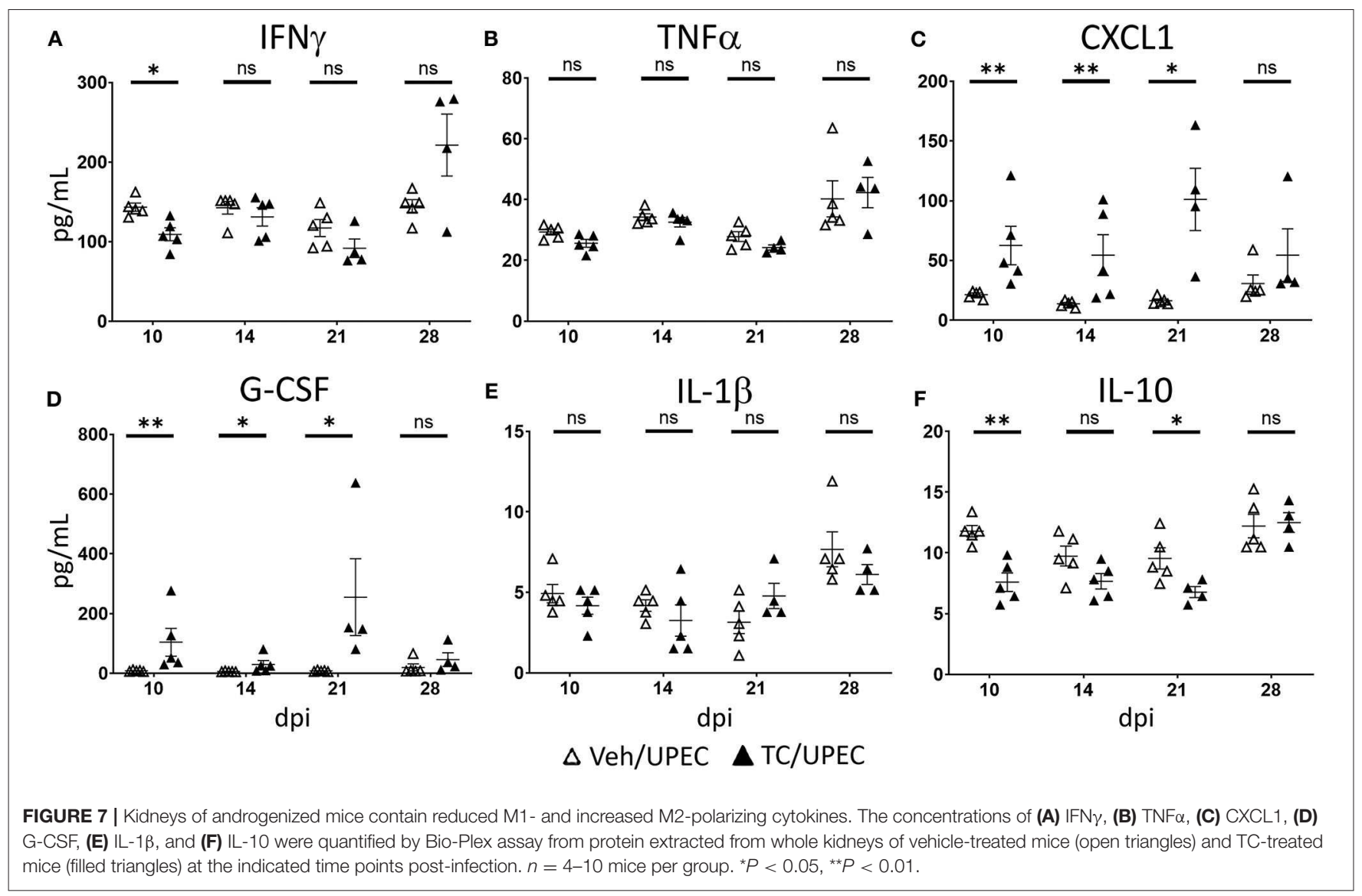

macrophages or alternatively activated M2 macrophages (98). This variance in polarization states appears to be environmentally dependent, with unstimulated monocytes and macrophages favoring an M1 phenotype (56-59), while LPS stimulation before activin A treatment skews these cells toward an M2 phenotype (60-64). During active bacterial infection, as in our model, the kidney is exposed to extensive LPS stimulation. This, combined with the increase in activin A, caused androgenized mice to have a sustained preponderance of M2 macrophages. When we examined the specific polarization states of these M2 cells, we found that TC-treated mice harbored significantly more M2a macrophages at all time points beginning $14 \mathrm{dpi}$. Macrophage polarization and proliferation occurs within the injured kidney, and M2 macrophages are highly important for repair of non-infectious renal injury (99-101). Specifically, M2a macrophages are known to be pro-fibrotic, enhancing TGF $\beta 1$ expression, cell growth, tissue repair, and matrix remodeling (39-42). During optimal recovery from tissue injury, this M2a population subsides as they differentiate toward (and are replaced by) immunoregulatory M2b and M2c macrophages, allowing the inflammatory response to abate and the affected tissue to return to a healed state $(36,96,102,103)$. In our model, while $\mathrm{M} 2 \mathrm{~b}$ and M2c numbers increased slightly over time in both TC- and vehicle-treated mice, the augmented M2a population in androgenized mice did not subside. The persistence of these M2a macrophages would act to prolong the pro-fibrotic state, prevent resolution of inflammation, and favor the androgen-enhanced renal scarring we have shown previously $(15,16)$.

Macrophage polarization is also highly dependent on secreted cytokines that are secreted by the injured tissue and the macrophages themselves $(27,96)$. M1 polarization occurs via stimulation with several pro-inflammatory signals (e.g., LPS and IFN $\gamma$, with ensuing TNF $\alpha$, and IL-6 production) (15-23), as are normally elicited early after bacterial infection of the urinary tract (104-106). M2 macrophages are sensitive to a variety of Th2 cytokines, including CXCL1, G-CSF and IL-10 $(27,31-33)$. The whole-kidney cytokine profiles following UPEC infection aligned with the macrophage polarization states we observed, with androgenized mice exhibiting suppressed IFN $\gamma$ and unaltered TNF $\alpha$, accompanied by increased CXCL1 and GCSF. The depressed IL-10 levels during infection in androgenized mice may hinder the adoption of M2b or M2c phenotypes, restraining kidney macrophages in a prolonged $\mathrm{M} 2 \mathrm{a}$ state.

In total, our data indicate that testosterone exposure alters the typical response to renal UPEC infection, pushing the kidney toward a dysfunctional healing process through increased activin A signaling and altered cytokine release. These signals encourage the recruited monocytes to polarize toward and persist as M2a macrophages for weeks in the kidney, preventing bacterial clearance and proper resolution of inflammation. A deeper understanding of how testosterone regulates these signals may allow us to modulate this immune 
response to help mitigate adverse long-term sequelae of severe pyelonephritis.

\section{DATA AVAILABILITY STATEMENT}

The datasets generated for this study are available on request to the corresponding author.

\section{ETHICS STATEMENT}

The animal study was reviewed and approved by the Institutional Animal Care and Use Committee, Washington University School of Medicine.

\section{AUTHOR CONTRIBUTIONS}

$\mathrm{TH}, \mathrm{KH}$, and $\mathrm{DH}$ conceived the study. TH, CC, AD, and JG designed and performed experiments. $\mathrm{DH}$ and $\mathrm{KH}$ critically

\section{REFERENCES}

1. Foxman B, Barlow R, D’Arcy H, Gillespie B, Sobel JD. Urinary tract infection: self-reported incidence and associated costs. Ann Epidemiol. (2000) 10:50915. doi: 10.1016/S1047-2797(00)00072-7

2. Hummers-Pradier E, Ohse AM, Koch M, Heizmann WR, Kochen MM. Urinary tract infection in men. Int J Clin Pharmacol Ther. (2004) 42:360-6. doi: $10.5414 / \mathrm{CPP} 42360$

3. Wettergren B, Jodal U, Jonasson G. Epidemiology of bacteriuria during the first year of life. Acta Podiatrica. (1985) 74:925-33. doi: 10.1111/j.1651-2227.1985.tb10059.x

4. Foxman B. Epidemiology of urinary tract infections: incidence, morbidity, and economic costs. Am J Med. (2003) 113:5S-13. doi: 10.1016/S0002-9343(02)01054-9

5. Ruben FL, Dearwater SR, Norden CW, Kuller LH, Gartner K, Shalley A, et al. Clinical infections in the noninstitutionalized geriatric age group: methods utilized and incidence of infections: the pittsburgh good health study. Am J Epidemiol. (1995) 141:145-57. doi: 10.1093/oxfordjournals.aje.a117402

6. Shaikh N, Morone NE, Bost JE, Farrell MH. Prevalence of urinary tract infection in childhood: a meta-analysis. Pediatr Infect Dis J. (2008) 27:302-8. doi: 10.1097/INF.0b013e31815e4122

7. Lipsky BA. Urinary tract infections in men. epidemiology, pathophysiology, diagnosis and treatment. Ann Intern Med. (1989) 110:138-50. doi: 10.7326/0003-4819-110-2-138

8. Shaikh N, Mattoo TK, Keren R, Ivanova A, Cui G, Moxey-Mims $\mathrm{M}$, et al. Early antibiotic treatment for pediatric febrile urinary tract infection and renal scarring. JAMA Pediatr. (2016) 170:848-54. doi: 10.1001/jamapediatrics.2016.1181

9. Foxman B, Klemstine KL, Brown PD. Acute pyelonephritis in US hospitals in 1997: hospitalization and in-hospital mortality. Ann Epidemiol. (2003) 13:144-50. doi: 10.1016/S1047-2797(02)00272-7

10. Efstathiou SP, Pefanis AV, Tsioulos DI, Zacharos ID, Tsiakou AG, Mitromaras AG, et al. Acute pyelonephritis in adults: prediction of mortality and failure of treatment. Arch Intern Med. (2003) 163:1206-12. doi: 10.1001/archinte.163.10.1206

11. Nicolle LE, Friesen D, Harding GK, Roos LL. Hospitalization for acute pyelonephritis in Manitoba, Canada, during the period from 1989 to 1992. impact of diabetes, pregnancy, and aboriginal origin. Clin Infect Dis. (1996) 22:1051-6. doi: 10.1093/clinids/22.6.1051

12. Ki M, Park T, Choi B, Foxman B. The epidemiology of acute pyelonephritis in South Korea, 1997-1999. Am J Epidemiol. (2004) 160:98593. doi: 10.1093/aje/kwh308 reviewed the data. TH generated the first manuscript draft. TH, $\mathrm{DH}, \mathrm{JG}$, and $\mathrm{KH}$ edited the manuscript. All authors contributed to the article and approved the submitted version.

\section{FUNDING}

This work was supported by NIH grants P50-DK064540 and R01-DK111541 (to DH). TH was supported by NIH grant T32-DK007126. The LSM880 Airyscan confocal microscope was purchased with support from the NIH Office of Research Infrastructure Programs (ORIP) under grant S10-OD021629.

\section{SUPPLEMENTARY MATERIAL}

The Supplementary Material for this article can be found online at: https://www.frontiersin.org/articles/10.3389/fimmu. 2020.01641/full\#supplementary-material

13. Calderon-Margalit R, Golan E, Twig G, Leiba A, Tzur D, Afek A, et al. History of childhood kidney disease and risk of adult end-stage renal disease. $N$ Engl J Med. (2018) 378:428-38. doi: 10.1056/NEJMoa1700993

14. Ricardo AC, Yang W, Sha D, Appel LJ, Chen J, Krousel-Wood M, et al. Sexrelated disparities in CKD progression. J Am Soc Nephrol. (2019) 30:137-46. doi: 10.1681/ASN.2018030296

15. Olson PD, McLellan LK, Liu A, Briden KL, Tiemann KM, Daugherty $\mathrm{AL}$, et al. Renal scar formation and kidney function following antibiotictreated murine pyelonephritis. Dis Model Mech. (2017) 10:1371-9. doi: $10.1242 / \mathrm{dmm} .030130$

16. Olson PD, McLellan LK, Hreha TN, Liu A, Briden KE, Hruska KA, et al. Androgen exposure potentiates formation of intratubular communities and renal abscesses by Escherichia coli. Kidney Int. (2018) 94:502-13. doi: 10.1016/j.kint.2018.04.023

17. Kalish SV, Lyamina SV, Usanova EA, Manukhina EB, Larionov NP, Malyshev IY. Macrophages reprogrammed in vitro towards the M1 phenotype and activated with LPS extend lifespan of mice with Ehrlich ascites carcinoma. Med Sci Monit Basic Res. (2015) 21:226-34. doi: 10.12659/MSMBR.895563

18. Murphy BS, Sundareshan V, Cory TJ, Hayes D, Anstead MI, Feola DJ. Azithromycin alters macrophage phenotype. J Antimicrob Chemother. (2008) 61:554-60. doi: 10.1093/jac/dkn007

19. Ishizuka EK, Ferreira MJ, Grund LZ, Coutinho EMM, Komegae EN, Cassado AA, et al. Role of interplay between IL- 4 and IFN- $\gamma$ in the in regulating M1 macrophage polarization induced by Nattectin. Int Immunopharmacol. (2012) 14:513-22. doi: 10.1016/j.intimp.2012.08.009

20. Venturin GL, Chiku VM, Silva KLO, de Almeida BFM, de Lima VMF. M1 polarization and the effect of PGE2 on TNF- $\alpha$ production by lymph node cells from dogs with visceral leishmaniasis. Parasite Immunol. (2016) 38:698-704. doi: 10.1111/pim.12353

21. Komada T, Chung H, Lau A, Platnich JM, Beck PL, Benediktsson H, et al. Macrophage uptake of necrotic cell DNA activates the AIM2 inflammasome to regulate a proinflammatory phenotype in CKD. J Am Soc Nephrol. (2018) 29:1165-81. doi: 10.1681/ASN.2017080863

22. Lv LL, Tang PMK, Li CJ, You YK, Li J, Huang XR, et al. The pattern recognition receptor, mincle, is essential for maintaining the M1 macrophage phenotype in acute renal inflammation. Kidney Int. (2017) 91:587-602. doi: 10.1016/j.kint.2016.10.020

23. Anders HJ, Suarez-Alvarez B, Grigorescu M, Foresto-Neto O, Steiger S, Desai J, et al. The macrophage phenotype and inflammasome component NLRP3 contributes to nephrocalcinosis-related chronic kidney disease independent from IL-1-mediated tissue injury. Kidney Int. (2018) 93:656-69. doi: 10.1016/j.kint.2017.09.022 
24. Davies LC, Jenkins SJ, Allen JE, Taylor PR. Tissue-resident macrophages. Nat Immunol. (2013) 14:986-95. doi: 10.1038/ni.2705

25. Galli SJ, Borregaard N, Wynn TA. Phenotypic and functional plasticity of cells of innate immunity: macrophages, mast cells and neutrophils. Nat Immunol. (2011) 12:1035-44. doi: 10.1038/ni.2109

26. Rock KL, Lai JJ, Kono H. Innate and adaptive immune responses to cell death. Immunol Rev. (2011) 243:191-205. doi: 10.1111/j.1600-065X. 2011.01040.x

27. Mantovani A, Sica A, Sozzani S, Allavena P, Vecchi A, Locati M. The chemokine system in diverse forms of macrophage activation and polarization. Trends Immunol. (2004) 25:677-86. doi: 10.1016/j.it. 2004.09.015

28. Hennemann B, Kreutz M, Rehm A, Andreesen R. Effect of granulocytemacrophage colony-stimulating factor treatment on phenotype, cytokine release and cytotoxicity of circulating blood monocytes and monocyte-derived macrophages. Br J Haematol. (1998) 102:1197-203. doi: 10.1046/j.1365-2141.1998.00922.x

29. Wilson HM, Chettibi S, Jobin C, Walbaum D, Rees AJ, Kluth DC. Inhibition of macrophage nuclear factor- $\kappa \mathrm{B}$ leads to a dominant anti-inflammatory phenotype that attenuates glomerular inflammation in vivo. Am J Pathol. (2005) 167:27-37. doi: 10.1016/S0002-9440(10)62950-1

30. Onore CE, Careaga M, Babineau BA, Schwartzer JJ, Berman RF, Ashwood P. Inflammatory macrophage phenotype in BTBR T+tf/J mice. Front Neurosci. (2013) 7:158. doi: 10.3389/fnins.2013.00158

31. Hamilton JA. Colony-stimulating factors in inflammation and autoimmunity. Nat Rev Immunol. (2008) 8:533-44. doi: 10.1038/nri2356

32. Wang $\mathrm{N}$, Liang $\mathrm{H}$, Zen $\mathrm{K}$. Molecular mechanisms that influence the macrophage M1-M2 polarization balance. Front Immunol. (2014) 5:614. doi: 10.3389/fimmu.2014.00614

33. Yan JJ, Ryu JH, Piao H, Hwang JH, Han D, Lee SK, et al. Granulocyte colonystimulating factor attenuates renal ischemia-reperfusion injury by inducing myeloid-derived suppressor cells. J Am Soc Nephrol. (2020) 31:731-46. doi: 10.1681/ASN.2019060601

34. Jenkins SJ, Ruckerl D, Cook PC, Jones LH, Finkelman FD, Van Rooijen $\mathrm{N}$, et al. Local macrophage proliferation, rather than recruitment from the blood, is a signature of TH2 inflammation. Science. (2011) 332:1284-8. doi: $10.1126 /$ science. 1204351

35. Jenkins SJ, Ruckerl D, Thomas GD, Hewitson JP, Duncan S, Brombacher F, et al. IL-4 directly signals tissue-resident macrophages to proliferate beyond homeostatic levels controlled by CSF-1. J Exp Med. (2013) 210:2477-91. doi: 10.1084/jem.20121999

36. Martinez FO, Sica A, Mantovani A, Locati M. Macrophage activation and polarization. Front Biosci. (2008) 13:453-61. doi: 10.2741/2692

37. Savill J, Gregory C, Haslett C. Eat me or die. Science. (2003) 302:1516-7. doi: 10.1126/science. 1092533

38. Serhan CN, Savill J. Resolution of inflammation: the beginning programs the end. Nat Immunol. (2005) 6:1191-7. doi: 10.1038/ni1276

39. Pan B, Liu G, Jiang Z, Zheng D. Regulation of renal fibrosis by macrophage polarization. Cell Physiol Biochem. (2015) 35:1062-9. doi: 10.1159/000373932

40. Tamura M, Aizawa R, Hori M, Ozaki H. Progressive renal dysfunction and macrophage infiltration in interstitial fibrosis in an adenine-induced tubulointerstitial nephritis mouse model. Histochem Cell Biol. (2009) 131:489-90. doi: 10.1007/s00418-009-0557-5

41. Zhang MZ, Wang X, Wang Y, Niu A, Wang S, Zou C, et al. IL-4/IL13-mediated polarization of renal macrophages/dendritic cells to an M2a phenotype is essential for recovery from acute kidney injury. Kidney Int. (2017) 91:375-86. doi: 10.1016/j.kint.2016.08.020

42. Cassol E, Cassetta L, Rizzi C, Alfano M, Poli G. M1 and M2a polarization of human monocyte-derived macrophages inhibits HIV1 replication by distinct mechanisms. J Immunol. (2009) 182:6237-46. doi: 10.4049/jimmunol.0803447

43. Lisi L, Stigliano E, Lauriola L, Navarra P, Dello Russo C. Proinflammatoryactivated glioma cells induce a switch in microglial polarization and activation status, from a predominant $\mathrm{M} 2 \mathrm{~b}$ phenotype to a mixture of M1 and M2a/B polarized cells. ASN Neuro. (2014) 6:171-83. doi: 10.1042/AN20130045

44. Zhao X, Dai J, Xiao X, Wu L, Zeng J, Sheng J, et al. PI3K/Akt signaling pathway modulates influenza virus induced mouse alveolar macrophage polarization to M1/M2b. PLoS ONE. (2014) 9:e104506. doi: 10.1371/journal.pone.0104506

45. Avdic S, Cao JZ, McSharry BP, Clancy LE, Brown R, Steain M, et al. Human cytomegalovirus interleukin-10 polarizes monocytes toward a deactivated M2c phenotype to repress host immune responses. J Virol. (2013) 87:273-82. doi: 10.1128/JVI.00912-13

46. Spiller KL, Anfang RR, Spiller KJ, Ng J, Nakazawa KR, Daulton JW, et al. The role of macrophage phenotype in vascularization of tissue engineering scaffolds. Biomaterials. (2014) 35:4477-88. doi: 10.1016/j.biomaterials.2014.02.012

47. Tang L, Zhang H, Wang C, Li H, Zhang Q, Bai J. M2A and M2C macrophage subsets ameliorate inflammation and fibroproliferation in acute lung injury through interleukin-10 pathway. Shock. (2017) 48:119-29. doi: 10.1097/SHK.0000000000000820

48. Lu J, Cao Q, Zheng D, Sun Y, Wang C, Yu X, et al. Discrete functions of M2a and M2c macrophage subsets determine their relative efficacy in treating chronic kidney disease. Kidney Int. (2013) 84:745-55. doi: 10.1038/ki.2013.135

49. Chaves LD, Mathew L, Shakaib M, Chang A, Quigg RJ, Puri TS. Contrasting effects of systemic monocyte/macrophage and CD4+ T cell depletion in a reversible ureteral obstruction mouse model of chronic kidney disease. Clin Dev Immunol. (2013) 2013:836989. doi: 10.1155/2013/836989

50. Michel U, Ebert S, Phillips D, Nau R. Serum concentrations of activin and follistatin are elevated and run in parallel in patients with septicemia. Eur J Endocrinol. (2003) 148:559-64. doi: 10.1530/eje.0.1480559

51. Michel U, Shintani Y, Nau R. Serum follistatin concentrations are increased in patients with septicaemia. Clin Endocrinol. (1998) 48:413-7. doi: 10.1046/j.1365-2265.1998.00484.x

52. Hübner G, Qianjin H, Smola H, Werner S. Strong induction of activin expression after injury suggests an important role of activin in wound repair. Dev Biol. (1996) 173:490-8. doi: 10.1006/dbio.1996.0042

53. Cruise BA, Xu P, Hall AK. Wounds increase activin in skin and a vasoactive neuropeptide in sensory ganglia. Dev Biol. (2004) 271:1-10. doi: 10.1016/j.ydbio.2004.04.003

54. Becker JC, Hertel M, Markmann A, Shahin M, Werner S, Domschke W, et al. Dynamics and localization of activin A expression in rat gastric ulcers. Scand J Gastroenterol. (2003) 38:260-7. doi: 10.1080/00365520310000636a

55. Yamashita S, Maeshima A, Kojima I, Nojima Y. Activin A is a potent activator of renal interstitial fibroblasts. J Am Soc Nephrol. (2004) 15:91-101. doi: 10.1097/01.ASN.0000103225.68136.E6

56. Maeshima A, Mishima K, Yamashita S, Nakasatomi M, Miya M, Sakurai N, et al. Follistatin, an activin antagonist, ameliorates renal interstitial fibrosis in a rat model of unilateral ureteral obstruction. Biomed Res Int. (2014) 2014:376191. doi: 10.1155/2014/376191

57. Kadiombo AT, Maeshima A, Kayakabe K, Ikeuchi H, Sakairi T, Kaneko $\mathrm{Y}$, et al. Involvement of infiltrating macrophage-derived activin $\mathrm{A}$ in the progression of renal damage in MRL-lpr mice. Am J Physiol Renal Physiol. (2017) 312:F297-304. doi: 10.1152/ajprenal.00191.2016

58. Werner S, Alzheimer C. Roles of activin in tissue repair, fibrosis, and inflammatory disease. Cytokine Growth Factor Rev. (2006) 17:157-71. doi: 10.1016/j.cytogfr.2006.01.001

59. Takei Y, Takahashi S, Nakasatomi M, Sakairi T, Ikeuchi H, Kaneko Y, et al. Urinary activin A is a novel biomarker reflecting renal inflammation and tubular damage in ANCA-associated vasculitis. PLoS ONE. (2019) 14:e0223703. doi: 10.1371/journal.pone.0223703

60. Li N, Cui X, Ge J, Li J, Niu L, Liu H, et al. Activin A inhibits activities of lipopolysaccharide-activated macrophages via TLR4, not of TLR2. Biochem Biophys Res Commun. (2013) 435:222-8. doi: 10.1016/j.bbrc.2013. 04.077

61. Nüsing RM, Barsig J. Induction of prostanoid, nitric oxide, and cytokine formation in rat bone marrow derived macrophages by activin $\mathrm{A}$. $\mathrm{Br} \mathrm{J}$ Pharmacol. (1999) 127:919-26. doi: 10.1038/sj.bjp.0702626

62. Wang Y, Cui X, Tai G, Ge J, Li N, Chen F, et al. A critical role of activin A in maturation of mouse peritoneal macrophages in vitro and in vivo. Cell $\mathrm{Mol}$ Immunol. (2009) 6:387-92. doi: 10.1038/cmi.2009.50

63. Ge J, Wang Y, Feng Y, Liu H, Cui X, Chen F, et al. Direct effects of activin A on the activation of mouse macrophage RAW264.7 cells. Cell Mol Immunol. (2009) 6:129-33. doi: 10.1038/cmi.2009.18 
64. Wang SY, Tai GX, Zhang PY, Mu DP, Zhang XJ, Liu ZH. Inhibitory effect of activin A on activation of lipopolysaccharide-stimulated mouse macrophage RAW264.7 cells. Cytokine. (2008) 42:85-91. doi: 10.1016/j.cyto.2008. 01.010

65. Zhang XJ, Li Y, Tai GX, Xu GY, Zhang PY, Yang Y, et al. Effects of activin A on the activities of the mouse peritoneal macrophages. Cell Mol Immunol. (2005) 2:63-7.

66. Ogawa K, Funaba M, Mathews LS, Mizutani T. Activin A stimulates type IV collagenase (matrix metalloproteinase-2) production in mouse peritoneal macrophages. J Immunol. (2000) 165:2997-3003. doi: 10.4049/jimmunol.165.6.2997

67. Zhou J, Tai G, Liu H, Ge J, Feng Y, Chen F, et al. Activin A downregulates the phagocytosis of lipopolysaccharide-activated mouse peritoneal macrophages in vitro and in vivo. Cell Immunol. (2009) 255:69-75. doi: 10.1016/j.cellimm.2008.11.001

68. Ogawa K, Funaba M, Chen Y, Tsujimoto M. Activin A functions as a Th2 cytokine in the promotion of the alternative activation of macrophages. $J$ Immunol. (2006) 177:6787-94. doi: 10.4049/jimmunol.177.10.6787

69. Olson PD, Hruska KA, Hunstad DA. Androgens enhance male urinary tract infection severity in a new model. J Am Soc Nephrol. (2016) 27:1625-34. doi: 10.1681/ASN.2015030327

70. Gamal D, Elkholi E, Nagy HM. The endocrine-metabolic disorders and adverse pregnancy outcomes in metabolically obese normal weight women with polycystic ovary syndrome. Womens Health Gynecol. (2016) 2:031.

71. Wang YC, Su HY, Liu JY, Chang FW, Chen CH. Maternal and female fetal virilization caused by pregnancy luteomas. Fertil Steril. (2005) 84:509. doi: 10.1016/j.fertnstert.2005.02.029

72. Li K, Xu W, Guo Q, Jiang Z, Wang P, Yue Y, et al. Differential macrophage polarization in male and female BALB/c mice infected with coxsackievirus B3 defines susceptibility to viral myocarditis. Circ Res. (2009) 105:353-64. doi: 10.1161/CIRCRESAHA.109.195230

73. Lee GT, Kim JH, Kwon SJ, Stein MN, Hong JH, Nagaya N, et al. Dihydrotestosterone increases cytotoxic activity of macrophages on prostate cancer cells via trail. Endocrinology. (2019) 160:2049-60. doi: 10.1210/en.2019-00367

74. Scotland RS, Stables MJ, Madalli S, Watson P, Gilroy DW. Sex differences in resident immune cell phenotype underlie more efficient acute inflammatory responses in female mice. Blood. (2011) 118:5918-27. doi: 10.1182/blood-2011-03-340281

75. ter Horst R, Jaeger M, Smeekens SP, Oosting M, Swertz MA, Li Y, et al. Host and environmental factors influencing individual human cytokine responses. Cell. (2016) 167:1111-24.e13. doi: 10.1016/j.cell.2016.10.018

76. Rettew JA, Huet-Hudson YM, Marriott I. Testosterone reduces macrophage expression in the mouse of Toll-like receptor 4, a trigger for inflammation and innate immunity. Biol Reprod. (2008) 78:432-7. doi: 10.1095/biolreprod.107.063545

77. Ashcroft GS, Mills SJ. Androgen receptor-mediated inhibition of cutaneous wound healing. J Clin Invest. (2002) 110:615-24. doi: 10.1172/JCI02 15704

78. Ashcroft GS, Horan MA, Ferguson MWJ. Aging alters the inflammatory and endothelial cell adhesion molecule profiles during human cutaneous wound healing. Lab Investig. (1998) 78:47-58.

79. Yamate J, Sato K, Ide M, Nakanishi M, Kuwamura M, Sakuma S, et al. Participation of different macrophage populations and myofibroblastic cells in chronically developed renal interstitial fibrosis after cisplatininduced renal injury in rats. Vet Pathol. (2002) 39:322-33. doi: 10.1354/vp. 39-3-322

80. Kushiyama T, Oda T, Yamada M, Higashi K, Yamamoto K, Sakurai $\mathrm{Y}$, et al. Alteration in the phenotype of macrophages in the repair of renal interstitial fibrosis in mice. Nephrology. (2011) 16:522-35. doi: 10.1111/j.1440-1797.2010.01439.x

81. Braga TT, Correa-Costa M, Guise YFS, Castoldi A, de Oliveira CD, Hyane MI, et al. Signaling pathway is involved in renal fibrosis by favoring a TH2 immune response and activating alternative M2 macrophages. Mol Med. (2012) 18:1231-9. doi: 10.2119/molmed.2012.00131

82. Han Y, Ma FY, Tesch GH, Manthey CL, Nikolic-Paterson DJ. Role of macrophages in the fibrotic phase of rat crescentic glomerulonephritis.
Am J Physiol Ren Physiol. (2013) 304:F1043-53. doi: 10.1152/ajprenal.003 89.2012

83. Alikhan MA, Jones CV, Williams TM, Beckhouse AG, Fletcher AL, Kett $\mathrm{MM}$, et al. Colony-stimulating factor-1 promotes kidney growth and repair via alteration of macrophage responses. Am J Pathol. (2011) 179:1243-56. doi: 10.1016/j.ajpath.2011.05.037

84. Shen B, Liu X, Fan Y, Qiu J. Macrophages regulate renal fibrosis through modulating TGF $\beta$ superfamily signaling. Inflammation. (2014) 37:2076-84. doi: 10.1007/s10753-014-9941-y

85. Chen SL, Hung CS, Pinkner JS, Walker JN, Cusumano CK, Li Z, et al. Positive selection identifies an in vivo role for FimH during urinary tract infection in addition to mannose binding. Proc Natl Acad Sci USA. (2009) 106:22439-44. doi: 10.1073/pnas.0902179106

86. Kramann R, Schneider RK, DiRocco DP, Machado F, Fleig S, Bondzie $\mathrm{PA}$, et al. Perivascular Gli1+ progenitors are key contributors to injury-induced organ fibrosis. Cell Stem Cell. (2015) 16:51-66. doi: 10.1016/j.stem.2014.11.004

87. Hung CS, Dodson KW, Hultgren SJ. A murine model of urinary tract infection. Nat Protocol. (2009) 4:1230-43. doi: 10.1038/nprot.2009.116

88. Hannan TJ, Hunstad DA. A murine model for Escherichia coli urinary tract infection. Methods Mol Biol. (2016) 1333:159-75. doi: 10.1007/978-1-4939-2854-5_14

89. Suginos K, Kurosawas N, Nakamuras T, Takios K, Shimasakill S, Lingll $\mathrm{N}$, et al. Molecular heterogeneity of follistatin, an activin-binding protein. higher affinity of the carboxyl-terminal truncated forms for heparan sulfate proteoglycans on the ovarian granulosa cell. J Biol Chem. (1993) 268:1557987.

90. Nakamura T, Takio K, Eto Y, Shibai H, Titani K, Sugino H. Activinbinding protein from rat ovary is follistatin. Science. (1990) 247:836-8. doi: $10.1126 /$ science. 2106159

91. Inouye S, Guo Y, Depaolo L, Shimonaka M, Ling N, Shimasaki S. Recombinant expression of human follistatin with 315 and 288 amino acids: chemical and biological comparison with native porcine follistatin. Endocrinology. (1991) 129:815-22. doi: 10.1210/endo-129-2-815

92. Humphreys BD. Mechanisms of renal fibrosis. Annu Rev Physiol. (2017) 80:309-26. doi: 10.1146/annurev-physiol-022516-034227

93. Vannella KM, Wynn TA. Mechanisms of organ injury and repair by macrophages. Annu Rev Physiol. (2017) 79:593-617. doi: 10.1146/annurev-physiol-022516-034356

94. Sindrilaru A, Scharffetter-Kochanek K. Disclosure of the culprits: macrophages-versatile regulators of wound healing. Adv Wound Care. (2013) 2:357-68. doi: 10.1089/wound.2012.0407

95. Meng XM, Nikolic-Paterson DJ, Lan HY. TGF- $\beta$ : the master regulator of fibrosis. Nat Rev Nephrol. (2016) 12:325-38. doi: 10.1038/nrneph.2016.48

96. Tang PMK, Nikolic-Paterson DJ, Lan HY. Macrophages: versatile players in renal inflammation and fibrosis. Nat Rev Nephrol. (2019) 15:144-58. doi: 10.1038/s41581-019-0110-2

97. Duan J, Liu X, Wang H, Guo SW. The M2a macrophage subset may be critically involved in the fibrogenesis of endometriosis in mice. Reprod Biomed Online. (2018) 37:254-68. doi: 10.1016/j.rbmo.2018.05.017

98. Morianos I, Papadopoulou G, Semitekolou M, Xanthou G. Activin A in the regulation of immunity in health and disease. J Autoimmun. (2019) 104:102314. doi: 10.1016/j.jaut.2019.102314

99. Lan HY, Nikolic-Paterson DJ, Mu W, Atkins RC. Local macrophage proliferation in the progression of glomerular and tubulointerstitial injury in rat anti-GBM glomerulonephritis. Kidney Int. (1995) 48:753-60. doi: 10.1038/ki.1995.347

100. Huen SC, Cantley LG. Macrophage-mediated injury and repair after ischemic kidney injury. Pediatr Nephrol. (2015) 30:199-209. doi: 10.1007/s00467-013-2726-y

101. Isbel NM, Hill PA, Foti R, Mu W, Hurst LA, Stambe C, et al. Tubules are the major site of M-CSF production in experimental kidney disease: correlation with local macrophage proliferation. Kidney Int. (2001) 60:61425. doi: 10.1046/j.1523-1755.2001.060002614.x

102. Mantovani A, Biswas SK, Galdiero MR, Sica A, Locati M. Macrophage plasticity and polarization in tissue repair and remodelling. J Pathol. (2013) 229:176-85. doi: 10.1002/path.4133 
103. Lech M, Anders HJ. Macrophages and fibrosis: how resident and infiltrating mononuclear phagocytes orchestrate all phases of tissue injury and repair. Biochim Biophys Acta. (2013) 1832:989-97. doi: 10.1016/j.bbadis.2012. 12.001

104. Hedges S, Svanborg C. The mucosal cytokine response to urinary tract infections. Int $J$ Antimicrob Agents. (1994) 4:89-93. doi: 10.1016/0924-8579(94)90039-6

105. Armbruster CE, Smith SN, Mody L, Mobley HLT. Urine cytokine and chemokine levels predict urinary tract infection severity independent of uropathogen, urine bacterial burden, host genetics, and host age. Infect Immun. (2018) 86:e00327-18. doi: 10.1128/IAI.00327-18

106. Sakumoto M, Matsumoto T, Mochida O, Takahashi K, Sakuma S, Kumazawa J. Urinary concentrations of cytokines in patients with pyelonephritis and cystitis. J Infect Chemother. (1998) 4:24-7. doi: 10.1007/BF02490062
Conflict of Interest: DH serves on the Board of Directors for BioVersys AG, Basel, Switzerland.

The remaining authors declare that the research was conducted in the absence of any commercial or financial relationships that could be construed as a potential conflict of interest.

Copyright (C) 2020 Hreha, Collins, Daugherty, Griffith, Hruska and Hunstad. This is an open-access article distributed under the terms of the Creative Commons Attribution License (CC BY). The use, distribution or reproduction in other forums is permitted, provided the original author(s) and the copyright owner(s) are credited and that the original publication in this journal is cited, in accordance with accepted academic practice. No use, distribution or reproduction is permitted which does not comply with these terms. 